\title{
Profile of Newly Diagnosed Type 1 Diabetic Children Admitted in Assiut University Children Hospital, Egypt
}

\author{
HANAA A. MOHAMMAD, M.D.; HEKMA S. FARGHALY, M.D.; EKRAAM M. ABD EL-KHALIK, M.D. and \\ SANAA A. MOHAMMAD, M.Sc.
}

The Department of Pediatrics, Faculty of Medicine, Assiut University

\begin{abstract}
Background: Since risk factors for development of type 1 diabetes mellitus vary greatly between different countries, so study of the epidemiological features of type 1 diabetes mellitus in our country may suggest the most important risk factors that could be prevented in the future. We aimed to identify the main epidemiological patterns and risk factors for newly diagnosed children with T1DM in Egypt.

Aim of Study: To determine the rate of newly diagnosed type 1 diabetes and to find out the different risk factors associated with type $1 \mathrm{DM}$ among infants and children attended Assiut University Children Hospital.
\end{abstract}

Patients and Methods: A descriptive case- control hospital based study included 179 case of newly diagnosed T1DM children who attended Assuit University Children Hospital and similar number as a controls during a period of one year.

Results: Our results indicate that our study children with T1DM had positive family history of DM, about $76 \%$ of them ingest junk foods, with late age of introduction of cereal and gluten, small for gestational age delivery, with prolonged normal vaginal delivery and high socioeconomic state.

Conclusion: Environmental factors have an important role in development of T1DM in the form of exposure to environmental risk factors during perinatal and neonatal period and also exposure to environmental factors during the first years of life as feeding pattern. There was no significant statistically difference as regard viral infection and maternal diseases.

Key Words: Newly diagnosed type 1 DM - Environmental factors - Mode of delivery perinatal and neonatal period - Feeding pattern and socioeconomic state.

\section{Introduction}

DIABETES mellitus is a condition where the cells of the body cannot utilize glucose properly. In type 1 there is reduced insulin production as the $\beta$-cells

Correspondence to: Dr. Sanaa A. Mohammad, E-Mail: mariamtabaly@gmail.com are gradually destroyed and an increased peripheral resistance in the uptake of insulin [1]. It represents about $10 \%$ of all cases of diabetes but it accounts for over $90 \%$ of childhood and adolescent diabetes [2]. The etiology of DM is still unknown, although it is thought to be the result of genetic, chemicals and environmental factors [3].

DM affect the developing countries of the world much more than their developed counterparts [4] The annual rate of increase in T1DM incidence ranges from 2-5\% in western European countries to $9 \%$ in eastern ones [5], in the Middle East and North Africa, there are about 60,000 cases of T1DM in children less than 15 years, the largest contributions to this number come from Saudi Arabia and Egypt whose estimates jointly account for nearly half of the region's total [6].

The number of people with diabetes is increasing evident from the findings of a series of global estimates of current and predicted future prevalence of diabetes there are 366 million people with diabetes; this is expected to rise to 552 million by 2030 , most people with diabetes live in low and middle-income countries [7]. It is the third commonest pediatric endocrine disease [8]

Although the genetic factors plays an important role in the development of $\mathrm{T} 1 \mathrm{DM}$, the rapid changes in incidence rate reported to occur within comparatively short time periods are more likely owing to changes in environmental risk factors [9].

The aim of the study to determine the rate of newly diagnosed type 1 diabetes and to find out the different risk factors associated with type 1 DM among infants and children attending Assiut University Children Hospital. 


\section{Patients and Methods}

This case-control study was carried out during a period of one year in Assiut University Children Hospital from April 2016 - April 2017. All newly diagnosed T1DM cases were included together with a comparative number of age and sex matched cases admitted in the hospital by diagnosis other than diabetes during the same period is considered as controls.

\section{Inclusion criteria:}

All patients fulfilling the diagnostic criteria of T1DM admitted in Assiut University Children Hospital.

\section{Exclusion criteria:}

- Patients presented with type 2 DM.

- Patients presented with secondary diabetes.

All cases and controls were subjected to history taking including:

1- Socio-demographic data including name, age, sex, month and season of birth, and residence. The socio-economic state was determined using modified Abd-El-Tawab (2004) scale.

\section{2- History of risk factors included:}

- Perinatal risk factors including maternal age, type of labor (normal, prolonged or cesarean), site of delivery (home, hospital or private clinic), weight at birth (small for gestational age $>2.5 \mathrm{~kg}$, normal $2.5-4.5 \mathrm{~kg}$ or large for gestational age $<4.5 \mathrm{~kg}$ ) and number of fetuses (single or twins).

- Nutritional risk factors including type of postnatal feeding (breast, formula or cow milk); for mixed feeding, breast feeding with formula was considered as a formula feeding and breast feeding with cow's milk was considered as a cow's milk feeding. Age of weaning, type of weaning food, supplementation of vitamin D.

- Lifetime history of exposure to certain viruses and vaccination history of the patients were recorded.

\section{Investigations done to cases included:}

- Random and fasting blood sugar, urine analysis for glucosuria and ketone bodies, arterial blood gases, $\mathrm{HbA}_{1 \mathrm{c}}$ and Fasting C-peptide.

\section{Statistical analysis:}

We used SPSS program Version 17 for windows for statistical analysis. Continuous data were expressed as mean, SD. Categorical data were expressed as number and percentages using OX2. $p$-values less than 0.05 was considered statistically significant, 95\% Confidence Interval (CI). Logistic regression was done to calculate the odds ratio to different risk factors.

\section{Results}

Table (1): Clinico-laboratory presentation of the studied patients with newly diagnosed type $1 \mathrm{DM}$.

\begin{tabular}{|c|c|}
\hline Items & $\begin{array}{c}\text { Patients }(n=179) \\
\text { No. }(\%) / \text { mean } \pm \text { SD }\end{array}$ \\
\hline $\begin{array}{l}\text { Age: (years): } \\
\quad 1-<6 \\
\quad 6-<12 \\
12-18 \\
\text { Mean } \pm \mathrm{SD}\end{array}$ & $\begin{array}{l}69(38.5) \\
59(33.0) \\
51(28.5) \\
7.83 \pm 4.68\end{array}$ \\
\hline $\begin{array}{l}\text { Sex: } \\
\quad \text { Male } \\
\text { Female }\end{array}$ & $\begin{array}{l}84(46.9) \\
95(53.1)\end{array}$ \\
\hline $\begin{array}{l}\text { Clinical presentation: } \\
\text { Classic presentation } \\
\text { DKA }\end{array}$ & $\begin{array}{l}59(32.9) \\
120(67.1)\end{array}$ \\
\hline $\begin{array}{l}\text { Body mas index: } \\
\text { Underweight } \\
\text { Normal } \\
\text { Overweight }\end{array}$ & $\begin{array}{l}61(34.1) \\
107(59.8) \\
11(6.1)\end{array}$ \\
\hline $\begin{array}{l}\text { HbAlC: } \\
\text { Normal } \\
\text { Mild increase } \\
\text { Moderate increase } \\
\text { Severe increase }\end{array}$ & $\begin{array}{l}9(5.0) \\
28(15.6) \\
44(24.6) \\
98(54.7)\end{array}$ \\
\hline $\begin{array}{l}\text { Fasting C-peptide: } \\
\text { Reduced } \\
\text { Normal }\end{array}$ & $\begin{array}{l}177(98.9) \\
2(1.1)\end{array}$ \\
\hline
\end{tabular}

Table (2): Socio-demographic characteristics of the studied patients with newly diagnosed type $1 \mathrm{DM}$ versus controls.

\begin{tabular}{|c|c|c|c|c|c|}
\hline \multirow{2}{*}{ Items } & \multicolumn{2}{|c|}{$\begin{array}{l}\text { Patients } \\
(n=179)\end{array}$} & \multicolumn{2}{|c|}{$\begin{array}{l}\text { Control } \\
(n=179)\end{array}$} & \multirow{2}{*}{$\begin{array}{c}p- \\
\text { value }\end{array}$} \\
\hline & No. & $\%$ & No. & $\%$ & \\
\hline Age: (yrs) Mean \pm SD & \multicolumn{2}{|c|}{$7.83 \pm 4.68$} & \multicolumn{2}{|c|}{$7.39 \pm 4.84$} & 0.353 \\
\hline \multicolumn{6}{|l|}{ Sex: } \\
\hline Male & 84 & 46.9 & 89 & 49.7 & \multirow[t]{2}{*}{0.597} \\
\hline Female & 95 & 53.1 & 90 & 50.3 & \\
\hline \multicolumn{6}{|l|}{ Social class: } \\
\hline Low & 83 & 46.4 & 119 & 66.5 & \multirow[t]{3}{*}{$0.000 *$} \\
\hline Middle & 69 & 38.5 & 48 & 26.8 & \\
\hline High & 27 & 15.1 & 12 & 6.7 & \\
\hline \multicolumn{6}{|l|}{ Family history of DM: } \\
\hline Yes & 118 & 65.9 & 21 & 11.7 & $0.000 *$ \\
\hline \multicolumn{6}{|l|}{ Type of DM in family: } \\
\hline Type I & 7 & 5.9 & 0 & 0.0 & $0.015^{*}$ \\
\hline Type 2 & 107 & 90.7 & 21 & 100.0 & $0.000 *$ \\
\hline \multicolumn{6}{|l|}{ Degree of relationship: } \\
\hline First degree & 28 & 23.7 & 2 & 9.5 & \multirow[t]{2}{*}{0.247} \\
\hline Second degree & 90 & 76.3 & 19 & 90.5 & \\
\hline
\end{tabular}


Table (3): Perinatal and postnatal history of the studied patients with newly diagnosed type $1 \mathrm{DM}$ versus control.

\begin{tabular}{|c|c|c|c|c|c|}
\hline \multirow[t]{2}{*}{ Items } & \multicolumn{2}{|c|}{$\begin{array}{l}\text { Patients } \\
(\mathrm{n}=179)\end{array}$} & \multicolumn{2}{|c|}{$\begin{array}{l}\text { Control } \\
(n=179)\end{array}$} & \multirow{2}{*}{$\begin{array}{c}p- \\
\text { value }\end{array}$} \\
\hline & No. & $\%$ & No. & $\%$ & \\
\hline \multicolumn{6}{|c|}{ Maternal age at delivery: (yrs) : } \\
\hline$<20$ & 11 & 6.1 & 15 & 8.4 & 0.163 \\
\hline $20-40$ & 159 & 88.8 & 161 & 89.9 & \\
\hline$>40$ & 9 & 5.0 & 3 & 1.7 & \\
\hline Mean \pm SD & \multicolumn{2}{|c|}{$27.90 \pm 6.62$} & \multicolumn{2}{|c|}{$27.96 \pm 6.31$} & 0.764 \\
\hline \multicolumn{6}{|l|}{ Type of labor: } \\
\hline Normal & 100 & 55.86 & 101 & 56.42 & $0.037 *$ \\
\hline Prolonged & 22 & 12.29 & 9 & 5.02 & \\
\hline Cesarean section & 57 & 31.8 & 69 & 38.5 & \\
\hline \multicolumn{6}{|l|}{ Site of delivery: } \\
\hline Hospital & 93 & 52.0 & 94 & 52.5 & 0.687 \\
\hline Private clinic & 40 & 22.3 & 34 & 19.0 & \\
\hline At home & 46 & 25.7 & 51 & 28.5 & \\
\hline \multicolumn{6}{|l|}{ Birth weight: $(\mathrm{kg})$ : } \\
\hline Mean \pm SD & \multicolumn{2}{|c|}{$2.53 \pm 0.48$} & \multicolumn{2}{|c|}{$2.99 \pm 0.22$} & $0.012 *$ \\
\hline
\end{tabular}

Table (4): Nutritional risk factors of the studied patients with newly diagnosed type $1 \mathrm{DM}$ versus control.

\begin{tabular}{|c|c|c|c|c|c|}
\hline \multirow{2}{*}{ Items } & \multicolumn{2}{|c|}{$\begin{array}{l}\text { Patients } \\
(\mathrm{n}=179)\end{array}$} & \multicolumn{2}{|c|}{$\begin{array}{l}\text { Control } \\
(n=179)\end{array}$} & \multirow{2}{*}{$\begin{array}{c}p- \\
\text { value }\end{array}$} \\
\hline & No. & $\%$ & No. & $\%$ & \\
\hline \multicolumn{6}{|l|}{ Postnatal feeding: } \\
\hline Breastfeeding & 144 & 80.4 & 169 & 94.4 & $0.000 *$ \\
\hline Formula/cow milk & 35 & 19.6 & 10 & 5.6 & $0.000 *$ \\
\hline \multicolumn{6}{|c|}{ Supplementation of Vitamin D: } \\
\hline Yes & 76 & 42.5 & 70 & 39.1 & 0.519 \\
\hline No & 103 & 57.5 & 109 & 60.9 & \\
\hline
\end{tabular}

Table (5): Odds ratio of the risk factors of the studied patients with newly diagnosed type $1 \mathrm{DM}$ versus control.

\begin{tabular}{|c|c|c|c|c|c|c|}
\hline \multirow{2}{*}{ Items } & \multicolumn{2}{|c|}{$\begin{array}{l}\text { Patients } \\
(n=179)\end{array}$} & \multicolumn{2}{|c|}{$\begin{array}{l}\text { Control } \\
(n=179)\end{array}$} & \multirow{2}{*}{$\begin{array}{c}\text { OR } \\
(95 \% \mathrm{CI})\end{array}$} & \multirow{2}{*}{$\begin{array}{c}p- \\
\text { value }\end{array}$} \\
\hline & No. & $\%$ & No. & $\%$ & & \\
\hline \multicolumn{7}{|l|}{ Social class: } \\
\hline - Low & 83 & 46.4 & 119 & 66.5 & & \\
\hline - Middle & 69 & 38.5 & 48 & 26.8 & $\begin{array}{l}2.02 \\
(1.26-3.22)\end{array}$ & $0.005^{*}$ \\
\hline • High & 27 & 15.1 & 12 & 6.7 & $\begin{array}{l}3.28 \\
(1.57-6.85)\end{array}$ & $0.001 *$ \\
\hline \multicolumn{7}{|l|}{ Feeding history: } \\
\hline • Formula/cow & 35 & 19.6 & 10 & 5.6 & $\begin{array}{l}3.91 \\
(1.80-8.51)\end{array}$ & $0.000 *$ \\
\hline \multicolumn{7}{|l|}{ Family history of DM: } \\
\hline - Yes & 118 & 65.9 & 21 & 11.7 & 14.55 & $0.000 *$ \\
\hline • No & 61 & 34.1 & 158 & 88.3 & $(8.40-25.23)$ & \\
\hline \multicolumn{7}{|l|}{ Type of normal labor: } \\
\hline • Prolonged & 22 & 18.0 & 9 & 8.2 & $\begin{array}{l}2.98 \\
3.07-18.19)\end{array}$ & $0.028 *$ \\
\hline - Normal & 100 & 82.0 & 101 & 91.8 & & \\
\hline \multicolumn{7}{|l|}{ Birth weight: $(\mathrm{Kg})$ : } \\
\hline $\begin{array}{l}\text { - Small for gestational } \\
\text { age }\end{array}$ & 15 & 8.4 & 4 & 2.2 & $\begin{array}{l}4.08 \\
(1.33-12.54)\end{array}$ & $0.014 *$ \\
\hline • Normal weight & 161 & 89.9 & 175 & 97.8 & & - \\
\hline
\end{tabular}

\section{Discussion}

The prevalence of diabetes is steadily increasing everywhere, most markedly in the world's middleincome countries [10]. In the present study, 179 new cases of T1DM were recorded over a period of 1 year in our hospital.

In this study, T1DM was near equal in female and male (53.1\%), (46.9\%), a minor male excess in incidence have been reported in populations of European origin and a slight female excess in populations of African or Asian origin [11]. Regarding the age of the studied cases, $38.5 \%$ of cases were in the age group 1-6 years compared to $33.0 \%$ in the age group 6-12 years and $28.5 \%$ in the age group 12-18 years. Other reports demonstrate the increased rate of diabetes in children younger than 5 years old [12]. It has long been reported that T1DM has a bimodal allotment with one peak at 4-6 years of age and a second in early puberty (10-14 years of age) [13]. This change in the age incidence of the disease may raise the question about what early life changes did children are exposed to.

In this study, history suggestive early childhood infection showed no significant difference between type 1 diabetic cases and controls $(3.3 \%$ vs. $0.6 \%$ $p: 0.123)$. However several controversial reports in this issue showed reduced risk of type 1 diabetes in children exposed to infection early in life and this could reflect the protection afforded by exposure to infections and consequently may provide support for the hygiene hypothesis [14]. On the other hand, Ismail et al., [15] in Egypt and SnellBergeon et al., [16] studies revealed that early childhood infections (measles, mumps, and varicella) were significantly associated with T1DM. A study in Sweden [17] reported that, data from experimental animals as well as in vitro studies indicate that various viruses are clearly able to stimulate the development of T1DM via different mechanisms including direct $\beta$-cell lysis, by activation of auto-reactive T-cell, loss of regulatory $\mathrm{T}$-cell and molecular mimicry.

In this study, family history of diabetes as a whole as well as either type 1 or 2 diabetes were significantly higher in patients than controls (Table 2) and odds ratio 14.55 (8.40-25.23). This finding is in agreement with other studies [18-20]. T1DM and T2DM frequently co-occur in the same family, suggesting common genetic susceptibility. Such mixed family history is associated with intermediate phenotype of diabetes; insulin resistance and cardiovascular complications in T1DM [21]. In con- 
trast, a study in Italy reported that, a family history of T2DM did not influence the risk of T1DM [22]

Feeding pattern in early life (breast or formula/ cow milk) was assessed in this study and showed that formula/cow milk feeding represents $(19.6 \%)$ of cases compared to controls (5.6\%) with significant $p$-value (0.000) and odds ratio 3.91 (1.808.51). Similar results were reported by several studies. Visalli et al., Goldfarb and Holmberg et al., [23-25] found that breast feeding less than 6 months is an important factor among diabetic children. They added that breast feeding modifies the risk of 3 -cells autoimmunity even years after finishing breast feeding. Goldfarb [24] in Sweden added more evidence that cow's milk proteins trigger T1DM where antibodies to bovine $\beta$ lactoglobulin were detected in the serum of children with diabetes in contrast to those without diabetes. These findings may support the suggestions for the protective role of breast feeding on one hand and the early formula and cow's milk introduction as a risk factor for development of T1 DM on the other hand. However, Hummel et al., [26] in Germany, did not confirm the role of the duration of the breast feeding or the introduction of cow's milk feeding as a risk factor for T1D.

In the present study, $42.5 \%$ of the diabetic children were taking Vitamin D as a supplement compare to $39.1 \%$ of controls with no significant difference. In contrast, a large case-control study in Norway concluded that Vitamin D supplement given to the infants at least five times a week was associated with significant reduction in diabetes risk compared with healthy subjects [27]. Similarly, Hyppönen et al., [28] found a significantly reduced risk for T1DM in a birth cohort study when high dose Vitamin D supplementation was given regularly or irregularly.

In this study we found that prolonged labor represent $12.29 \%$ of the cases and $5.02 \%$ of controls with significant $p$-value 0.037 . This result is similar to study done by Stene et al., [29] who suggested that, an increased risk for T1DM is predicted by complicated vaginal delivery but not cesarean delivery. In contrast another report suggested cesarean delivery as predictor to faster progression to T1DM [30]. Perhaps the stress of a complicated vaginal delivery affecting the fetal immune system, or other unknown factors complicating the birth or leading to a decision to not have a cesarean delivery, may be related to T1DM risk. It is of great concern to mention that there was near significant statistical difference between cases and controls as regard multiple pregnancy (3.9\% vs. $0.6 \%, p: 0.067)$. This result may also support the stress as a risk factor for T1DM.

As regard maternal age at time of delivery, we found no significant difference between cases and controls. Other studies have observed an association with older maternal age and type 1 DM [31-35] The increased risk associated with older maternal age may be related to higher socioeconomic state and improved living conditions for children of older mothers compared with children of the youngest mothers. The increased obstetric risk for type $1 \mathrm{DM}$ in children of older mothers might also be attributed to more complicated deliveries, causing "stress"-induced pancreatic dysfunction as suggested by the overload hypothesis.

In this study according to birth weight, we found that $8.4 \%$ of cases were small for gestational age compared to $2.2 \%$ of controls with significant $p$-value (0.010) (Table 3 ) and odds ratio 4.08 (1.3312.54). This result is similar to a Swedish study which reported that, small for gestational age is linked with increased risk of metabolic abnormalities as diabetes type 1 [36]. In contrast, Robertson et al., [37] didn't find any association between birth weight and risk of T1DM in children under 15 years old in Grampian, Scotland. However, a Swedish study found that children who developed T1 DM tended to have a larger for gestational age weight [38]

\section{In Conclusion:}

From this study we can conclude that environmental factors have an important role in the development of T1DM especially those during the perinatal and neonatal periods. Also changes in the feeding pattern are thought to play an important role in triggering the immune process and the development of T1DM. Further larger multicenter studies are needed to elucidate this risk.

\section{References}

1- CHATTERJEE S. and P. BISWAS: Psycho-social stigma among type 1 diabetes mellitus patients. Indian Journal of Medical Specialities, 4 (1), 2013.

2- THUNANDER M., et al.: Incidence of type 1 and type 2 diabetes in adults and children in Kronoberg, Sweden. Diabetes research and clinical practice, 82 (2): p. 24755, 2008.

3- DANEMAN D.: Type 1 diabetes. The Lancet, 367 (9513): p. 847-58, 2006.

4- WHITING D.R., et al.: IDF diabetes atlas: Global estimates of the prevalence of diabetes for 2011 and 2030. Diabetes research and clinical practice, 94 (3): p. 311-21, 2011. 
5- ATKINSON, M.A., G.S. EISENBARTH and A.W. MICHELS: Type 1 diabetes. The Lancet, 383 (9911): p. 6982, 2014.

6- ZAYED H.: Epidemiology of diabetic ketoacidosis in Arab patients with type 1 diabetes: A systematic review. International Journal of Clinical Practice, 70 (3): p. 18695, 2016.

7- ROWLEY W.R. and C. BEZOLD: Creating public awareness: State 2025 diabetes forecasts. Population Health Management, 15 (4): p. 194-200, 2012.

8- BORCHERS A.T., R. UIBO and M. GERSHWIN: The geoepidemiology of type 1 diabetes. Autoimmunity reviews, 9 (5): p. A355-A65, 2010.

9- KNIP M. and O. SIMELL: Environmental triggers of type 1 diabetes. Cold Spring Harbor perspectives in medicine, 2 (7): p. a007690, 2012.

10- VAZQUEZ G., et al.: Comparison of body mass index, waist circumference, and waist/hip ratio in predicting incident diabetes: A meta-analysis. Epidemiologic reviews, 29 (1): p. 115-28, 2007.

11- KYVIK K.O., et al.: The epidemiology of type 1 diabetes mellitus is not the same in young adults as in children. Diabetologia, 47 (3): p. 377-84, 2004.

12- FELNER E.I. and P.C. WHITE: Improving management of diabetic ketoacidosis in children. Pediatrics, 108 (3): p. 735-40, 2001.

13- FELNER E.I., et al.: Genetic interaction among three genomic regions creates distinct contributions to earlyand late-onset type 1 diabetes mellitus. Pediatric diabetes, 6 (4): p. 213-20, 2005

14- CARDWELL C.R., et al.: Atopy, home environment and the risk of childhood-onset type 1 diabetes: A populationbased case-control study. Pediatric diabetes, 9 (3pt1): p. 191-6, 2008.

15- ISMAIL N.A., et al.: Epidemiology and management of type 1 diabetes mellitus at the Ain Shams University Pediatric Hospital. J. Egypt Public Health Assoc., 83 (12): p. 107-32, 2008 .

16- SNELL-BERGEON J.K., et al.: Early Childhood Infections and the Risk of Islet Autoimmunity. Diabetes care, 35 (12): p. 2553-8, 2012.

17- VAN DER WERF N., et al.: Viral infections as potential triggers of type 1 diabetes. Diabetes/metabolism research and reviews, 23 (3): p. 169-83, 2007.

18- SIPETIC' S., et al.: Family history and risk of type 1 diabetes mellitus. Acta diabetologica, 39 (3): p. 111-5, 2002.

19- WAHLBERG J., et al.: Environmental factors related to the induction of beta-cell autoantibodies in 1-yr-old healthy children. Pediatric diabetes, 6 (4): p. 199-205, 2005.

20- MOUSSA M., et al.: Factors associated with type 1 diabetes in Kuwaiti children. Acta diabetologica, 42 (3): p. 129-37, 2005.

21- TUOMI T.: Type 1 and type 2 diabetes. Diabetes, 54 (suppl 2): p. S40-S5, 2005.
22- ALTOBELLI E., et al.: Family history and risk of insulindependent diabetes mellitus: A population-based casecontrol study. Acta diabetologica, 35 (1): p. 57-60, 1998.

23- VISALLI N., et al.: Environmental risk factors for type 1 diabetes in Rome and province. Archives of disease in childhood, 88 (8): p. 695-8, 2003.

24- GOLDFARB M.F.: Relation of time of introduction of cow milk protein to an infant and risk of type-1 diabetes mellitus. Journal of Proteome Research, 7 (5): p. 2165 7, 2008 .

25- HOLMBERG H., et al.: Short duration of breast-feeding as a risk-factor for 3 -cell autoantibodies in 5-year-old children from the general population. British Journal of Nutrition, 97 (1): p. 111-6, 2007.

26- HUMMEL M., et al.: No major association of breastfeeding, vaccinations, and childhood viral diseases with early islet autoimmunity in the German Babydiab Study. Diabetes care, 23 (7): p. 969-74, 2000.

27- STENE L.C., G. JONER and N.C.D.S. GROUP: Use of cod liver oil during the first year of life is associated with lower risk of childhood-onset type 1 diabetes: A large, population-based, case-control study. The American journal of clinical nutrition, 78 (6): p. 1128-34, 2003.

28- HYPPÖNEN E., et al.: Intake of vitamin D and risk of type 1 diabetes: A birth-cohort study. The Lancet, 358 (9292): p. 1500-3, 2001

29- STENE L.C., et al.: Perinatal factors and development of islet autoimmunity in early childhood: The diabetes autoimmunity study in the young. American Journal of Epidemiology, 160 (1): p. 3-10, 2004.

30- BONIFACIO E., et al.: Cesarean section and interferoninduced helicase gene polymorphisms combine to increase childhood type 1 diabetes risk. Diabetes, 60 (12): p. 33006, 2011.

31- BINGLEY P.J., et al.: Influence of maternal age at delivery and birth order on risk of type 1 diabetes in childhood: Prospective population based family study. B.M.J., 321 (7258): p. 420-4, 2000.

32- STENE L.C., et al.: Maternal and paternal age at delivery, birth order, and risk of childhood onset type 1 diabetes: Population based cohort study. B.M.J., 323 (7309): p. 369, 2001.

33- CARDWELL C., D. CARSON and C. PATTERSON: Parental age at delivery, birth order, birth weight and gestational age are associated with the risk of childhood Type 1 diabetes: A UK regional retrospective cohort study. Diabetic Medicine, 22 (2): p. 200-6, 2005.

34- SVENSSON J., et al.: Early childhood risk factors associated with type 1 diabetes-is gender important? European Journal of Epidemiology, 20 (5): p. 429-34, 2005.

35- HAYNES A., et al.: Perinatal risk factors for childhood Type 1 diabetes in Western Australia-a population-based study (1980-2002). Diabetic Medicine, 24 (5): p. 564-70, 2007.

36- CRUMP C., et al.: Risk of diabetes among young adults born preterm in Sweden. Diabetes Care, 34 (5): p. 1109 13, 2011. 
37- ROBERTSON L. and K. HARRILD: Maternal and neonatal risk factors for childhood type 1 diabetes: A matched case-control study. B.M.C. Public Health, 10 (1): p. 281, 2010.
38- CARD WELL C.R., et al.: Birthweight and the risk of childhood-onset type 1 diabetes: A meta-analysis of observational studies using individual patient data. Diabetologia, 53 (4): p. 641-51, 2010.

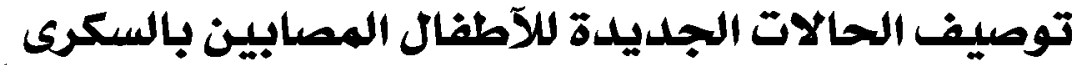

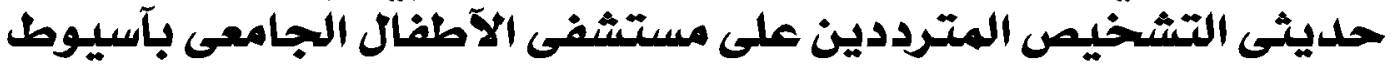

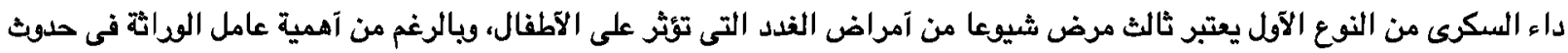

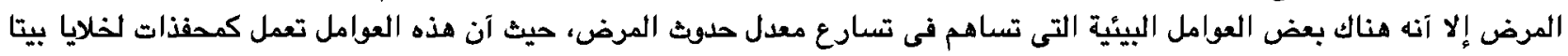

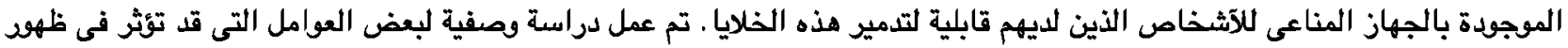

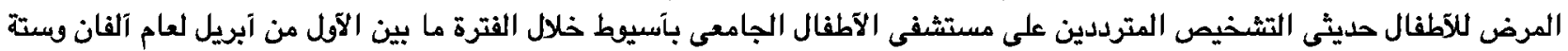

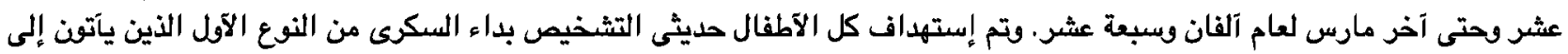

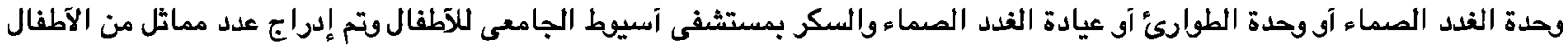

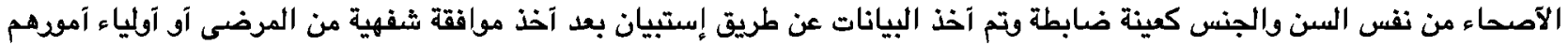
وتثمل اليانات: • الصفات الديموغرافية للمريض (السن، الجنس ومستوى المعيشة والإقامة).

• بيانات متعلقة بالآم فى فترة الحمل وما قبل الولادة (الإصابة بعدوى بكتيرية آو مرض السكرى آوحدوث إرتفاع بضغط الدم آثثاء الحمل). • عمر الآم عند الولادة، نوع الولادة ومكانها، عمر وقذن الطفل بعد الولادة.

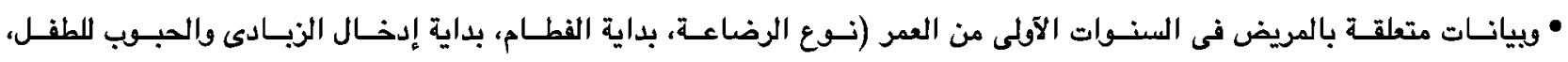
إدخال فيتامين د). • ت ت تاول الآطعمة المحفوظة. • • تعرض الطفل لعدوى بكتيرية آو فيروسية. • بداية ظهور آعراض المرض وما هى الآعراض. • ت تاريخ مرضى فى العائلة.

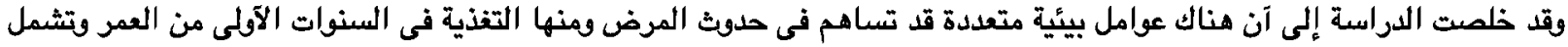

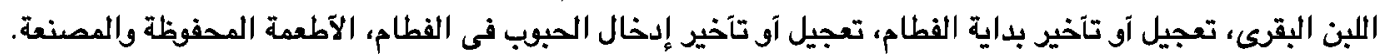
الحالة الإجتماعية المترفهة، عوامل آثاء الحمل وما بعد الولادة ومنها: - مضاعفات الولادة الطبيعية مثل طول فترة الولادة. - الولادة المبكرة ونقص ونن الطفل عند الولادة. - تعدض الطفل الرضيع للإصابة بضيق فى التنفس آو العلاج فى العناية المركزة. 